\title{
Islamic Scholar and Regional Development: Analyze on Sinan's Contribution in Civil Engineering
}

\author{
Halimi Mohd. Khalid ${ }^{1 *}$, Nur Zainatul Nadra Zainol ${ }^{2}$, Shakila Ahmad ${ }^{3}$, Mohd Hisyam Mohd Abdul Rahim ${ }^{4}$, Abdul \\ Shakor Borham ${ }^{5}$ \\ ${ }^{1}$ Department of Akidah and Education, Ahli Sunnah wal Jamaah Institute, Universiti Tun Hussein Onn Malaysia \\ ${ }^{2}$ Department of Research, Documentation \& Publication, Ahli Sunnah wal Jamaah Institute, Universiti Tun Hussein Onn Malaysia \\ ${ }^{3}$ Fellow Ahli Sunnah wal Jamaah Institute, Universiti Tun Hussein Onn Malaysia
${ }_{1,2,3,4,5}$ Department of Islamic Studies, Center for General Studies and Cocurricular, Universiti Tun Hussein Onn Malaysia, Parit Raja, \\ Batu Pahat, Johor \\ *Corresponding author E-mail: halimi@uthm.edu.my
}

\begin{abstract}
Muslims have been at the top of the glory of civilization with a combination of excellence achieved in the East and West. To the east, the progress made in Kufa, Baghdad and Damascus is a turning point towards the propagation of Islamic civilization. While on the west, Sicilian control has opened the eyes of the world. While the success achieved in Andalusia cannot be matched at that time by other European powers. Almost 14 centuries of Islam dominated the world stage. The development achieved in the aspects of science, architecture, science, technology and so on can not be matched at that time by any external force. This shows that the Islamic government has never forgotten the development aspect, but it is one of the important aspects of civilization. Among this achievement were contributed by Islamic scholar in Ottoman Empire such as Yusuf Sinauddin bin Abdul Mennan or Abdullah. He recognized as Mi'mar Sinan. This article aims to analyze the contribution of Sinan in regional development which was focusing in field of civil engineering. It involved content analysis as method for collecting the data. The result shows Sinan had significant contribution in two aspects namely in the construction of water aqueducts and bridges engineering. He also embedded the Islamic attributes in his works.
\end{abstract}

Keywords: Islamic Civilization; Islamic Scholar; Regional Development in Engineering; Uthmaniyah Empire; Sinan

\section{Introduction}

The discussion of Islamic golden age throughout the history and civilization, it is good to understand the meaning of the civilization itself. Manzur (1) in Lisan al-Arab uses the term madaniah, tamadun and hadarah to illustrate the meaning of civilization. Khaldūn (2) in his book Muqaddimah, he put forward the term umran and hadarah to define civilization as some normal circumstances and events beyond the merits, arising from developmental events. Civilization may increase with increasing progress. But it still needs to be based on humanity. Syed Naquib al-Attas (3)(1977) in his book defines civilization as a state of human life that has reached the level of tolerance and culture of the whole society. The opinions given by some of the above figures in their writing are more aimed at balanced development between the demands of the world and the demands of the hereafter. So religion plays a major role in shaping a strong civilization from its internal and external points. While the perspective of civilization from the western scholar glasses is more directed towards the development of material in nature without any religious intervention. This is because of the secularism that has spread and permeated the thinking of most western scholars who set aside religious affairs in matters of development and religion simply practice in churches and worship houses.

The definition of civilization according to western scholars between Toynbee (4) in his book A Study of History defines civilization as a kind of culture that develops within the city.
He added that civilization is also a group of thoughts from various manifestations, continuous orientation, a cultural style responsible for forming political, literary, religious and moral institutions. Darcy Riberio in his book The Civilized Society defines civilization is the peak of the achievement of a society in the process of progress. Hornby (5) in their dictionary The Progressive English Dictionary defines civilization as an increase in the achievement of human life from the setbacks to advancement in science, science, technology, politics, morals and so on.

\section{The Glory of Islamic civilization}

The aspects of civilization from the times of the anbiya' were inherited by the post-prophetic Muslims - nubuwwah. In the days of the khulafa 'al-Rasyidin, the importance of knowledge continues to be cultivated. Until the Umayyads and Abasiyyah governments, where Muslims were at the peak of knowledge and create a high civilization history. It continued until the time of Islamic rule ended after the fall of the Ottoman Ottoman caliphate in total in $1924 \mathrm{M}$. The Muslims in glory succeeded in creating a revolution of knowledge that became the subject of a western study. This is especially during the era of Islamic mastery in the west through the mastery of Andalusia and also the excellence of Islamic scientists in the east of Baghdad. There are some examples that are relevant to the creativity, creativity and innovation of the previous generation in producing theories, models and even state-of-the-art tools at the time. Areas that Muslims have ever mastered include 
Physics, Astronomy, Chemistry, Mathematics, Medicine, Geography, Science and Science. This is coupled with their mastery in the field of Philosophy and Islamic Thought. The characters involved in developing science include Jabir bin Hayan al-Kufi, an Islamic chemist who lived in the 8th century AD; al-Khawarizmi (840M), a figure in Falak, Geography and Mathematics who lived in the 9th century $\mathrm{AD}$ where he was responsible for bringing together and adapting Greek and Indian mathematics; al-Batani $(929 \mathrm{M})$ is a Muslim astronomer; al-Razi (1023M) and Ibn Sina $(1037 \mathrm{M})$ are the distinguished medical figures; al-Hasan ibn Haitham $(1020 \mathrm{M})$ a scientist in the field of natural science; Omar Khayyam who lived in the 12th century $\mathrm{AD}$ is well-known in Mathematics. The discovery of knowledge by these Islamic experts has affected the world and spread in stages to the west and east. The findings of these sciences are new findings and have never been met by other scientists before them or their contemporaries (6).

The glory of civilization had its own foundations. Throughout the history of Islamic rule, since the time of the Prophet s.a.w, Caliph al-Rashidin, Umayyad, Abasiyyah until the end of Islamic rule under the Ottoman Empire, there are some unique features that can be highlighted. According to Mohd Roslan (7) (2010), one of the main features of the historical aspect that needs to be emphasized were:

i. Excellence in science. This can not be separated if the serious desire to develop civilization is to be implemented. Islamic history suggests that the great cities are famous because of their scholarly activities that are progressing.

ii. Stability in the country through inter-racial relations. Racial harmony and tolerance have been emphasized since the time of the Prophet s.a.w, and practiced perfectly during the time of the Caliph al-Rasyidin. It is also practiced when Muslims dominate al-Sham regions such as Bayt al-Maqdis based on the al-Uhda al-Umariyyah document issued by Saidina Umar to Muslims and non-Muslims (8). This attitude can also be seen when Islam controls the western region like Andalusia as the freedom given to all Muslims and Jews by Abdul Rahman III.

iii. Stability of government and political administration. Without political and governmental stability, surely the excellence of Islamic civilization will not last long and it will burst into weakness of leadership. This stability is the pride of the people, despite the fact that some internal conflicts have arisen some small kingdoms that govern certain territories throughout the Islamic history. The existence of small kingdoms did not weaken despite the inevitable consequences of the existence of the Mamluk government rebel from Ayyubid's confrontation. However, the trail had to be faced and the result continued to strengthen the Islamic rule as a whole until the Islamic caliphate moved to the Ottoman Empire.

iv. Strength of defense thus preventing the country from attacking the enemy. The strength of the existing defense succeeded in maintaining the Caliphate of Islamiyyah until 1924M, which lasted about 85 years ago. Clearly, when Salahuddin al-Ayyubi recaptured the Bayt al-Maqdis city from the crusaders (8) it has proven that defense and military forces are an important aspect of the world today. In modern times, it seems quite impossible for the Islamic state to rival the west in terms of weaponry. This is actually demanding Muslims to regain control of these weapons sciences besides mastering another aspect of modern warfare namely cybertechnology and nature.

\section{Ottoman Empire (1299-1924M)}

The Ottoman Empire began after the collapse of the Abbasid Empire in the hands of the Mongol army in Baghdad. Emphasis on the field of science in this era when Sultan Mehmet II invites scholars from several countries like Persia and Andalus to come to Istanbul to develop their knowledge. He is also a patron of the scientific activities carried out, paying much money to them. In the Sultan Mehmet II waqf document, it clearly expresses his desire to make Istanbul a center for science development. This is evidenced by the establishment of Madrasah Fatih and Dar alta'lim in $1462 \mathrm{M}$ and completed in 1470M (9). The main purpose of this madrasah is to teach religious subjects such as fiqh. However, with the construction of hospitals and observatory stations adjacent to the madrasah, it is possible that science subjects such as medicine and astronomy are taught there (10). Teachers who teach at this madrasah should be proficient in both fields of religion and science such as logic, philosophy, mathematics and astronomy. While the curriculum in the madrasah is provided by scholars of expertise including a mathematician and astronomer from Samarkand, Ali Kuşcu (10).

Ipsirli (11) reports that, most historians have considered the mid16th century the peak of Ottoman rule. This is because, the success of the Ottoman government of the era played an active role in administration, military, and diplomacy as well as succeeding in promoting intellectual development especially in science and technology. Without a doubt, the sultan who ruled the Ottoman empire in the mid-16th centuy was Sultan Suleyman al-Qānūnī who held leadership in 1520M until 1566M. Emiralioglu (12) adds, the effect of the opening of Constantinople by Sultan Mehmed II became the catalyst for the Ottoman Empire's development of science and technology of the era of Sultan Suleyman al-Qānūnī. This is because Sultan Suleyman al-Qānūnī resumed the Sultan Mehmed II's legacy in adapting the Byzantine bureaucracy system to centralize its administration thereby transforming the space for the development of science and technology of the Ottoman government. Ogier Ghiselin de Busbecq, the Habsburg government ambassador explains that the Ottoman government of the Sultan Suleyman era al-Qānūnī, though separated by anti-Christian attitude from the point of view, has adapted many Western advances such as weapons, printing and other technologies. The Sultan and the scholars at that time allowed the adoption of Western progress aimed at developing and benefiting the Ottoman government in a jihadist battle against Western power (13). Lewis (14) in The emergence of modern Turkey stated that although the Ottoman Empire was hostile to and against Christians, however, they adapted many things from the West and adapted according to their culture and Islamic culture.

Sultan Suleyman al-Qānūnī also emphasized the learning of science and technology in the Ottoman government madrasahs. This proved that during his reign, the Ottoman Empire had about 324 madrasahs throughout the country. In addition there is also a special madrasah construction that focuses only on medical sciences such as Suleymaniye medical madrasah. According to Shaw and Shaw (15) and Ihsanoglu and Al-Hassani (16) the establishment of the Suleymaniye medical madrasah was established to train doctors who would serve in hospitals and the sultan's palace. The establishment of this madrasah became the most important factor in boosting the development of science and technology of the era of Sultan Suleyman al-Qānūnī. The management of the Madrasah is regulated by the health director's office.

\section{The Bibliographic of Sinan}

His real name is Yusuf Sinauddin bin Abdul Mennan or Abdullah. In Tezkiret-ul Bunyan, his name was recorded as Sinan bin Abdulmennan. According to the records contained in Tezkiret-ul Enbiye the name of this figure was recorded as Yusuf bin Abdullah.Sinan was born in a village called Agimas located near Kayseri Town in Antolith. There is no accurate agreement on the actual date of his birth. The scholars gave various dates to mark the year of his birth that was around 1489 until 1498 as a Christian.

In 1512, Sinan joined the Turkish elite military group through a system known as the Devsirme System. According to Aptullah Kuran, Sinan was brought to join this elite army in the early twenties. He went to Istanbul as a recruiter to the elite group and later converted to Islam. 
During his involvement in the field of architecture, Sinan was entrusted with joining many military operations. Sinan's participation in military operations has provided many advantages to him to secure a good position in the ranks of Turkish elite forces (Janissarie). The journey that Sinan had traveled to during the military campaigns had provided her the opportunity to visit some of the leading cities in Asia and Europe. This opportunity has contributed greatly to the process of acquiring knowledge for the purpose of construction and development of Sinan's career particularly in engineering and architecture.

\section{Methodology}

This paper objectively is to analyze the contribution of Sinan in regional development which was focusing in field of civil engineering. Thus the method used was qualitative method by usingthe content analysis method. Qualitative research is the process of finding information based on an understanding of data collection methods that are commonly used when reviewing a social problem (Cresswell, 2003). Through the method of content analysis, the method adopted is to describe objectively communication messages that have been printed, broadcasted or implied by hearing, acquiring and viewingthe text content either in words, pictures, symbols, ideas, themes, and any messages that have been communicated (Babbie, 2010). Therefore, collecting data through content analysis can provide information that is relevant to the issues and problems that have been studied.

\section{Discussions and Results}

\subsection{Sinan's Contributions in the Engineering Field}

The world generally knows that Mi'mar Sinan is a great name and is very synonymous with architecture. Belau is a renowned architect and famous in the history of the Ottoman Empire. Sinan has been entrusted to hold various important positions including as the chief architect who clearly portrays his credibility and talent as well as his abilities in the field of architecture.

This statement does not necessarily deny that Sinan's position and characteristic in engineering science. There are many records showing Sinan has started his career as a military engineer before being seriously involved in the architecture. The Oxford Dictionary of Islam notes:

Emerging from thr devshirme system, Sinan began his career as military engineer, eventually becoming chief architect in 1538 Dogan Kuban also states:

He must had seen all kinds of domical buildings, as he marched from Italy and the Balkan Azerbaijan and Syria in the various campaign of the Turkish army in which he served as an officer and engineer.

Through his work titled Sinan's Water Supply Syatem in Istanbul, Kazim Cecen states "A study of Sinan's work will instantly reflect that he was an outstanding engineer." While John Freely and Augusto Romano Burelli is of the view that:

The need for precision and structural clarity drove Sinan, an engineer and architect, to put outside the mosque the supports and buttresses that hold up the great shell of the dome.

In addition to assessing the unique characteristics and aesthetic values found in Sinan's work, there are some studies conducted by scholars who are investigating the work done by Sinan from the point of view of science and technical work. Muzzafer Ozgules in His work paper entitled "Sinan Scuptural Architecture in Istanbul" has assessed the work done by Sinan from both aspects of art and science. From the point of view of science, Muzzafer has quoted Erzen's views which have pointed out that Sinan has practiced his knowledge in engineering science, which refers to the field of engineering and structural engineering in the work it produces:

Nevertheless, one should also keep in mind that the structural form is connected to the aesthetic idea, and each effort to strength- en the structure becomes a feature of the aesthetic form of Sinan's work

Based on these statements clearly demonstrates that apart from being recognized as a leading architect, Sinan is also in fact an engineer. The errors in most of the architectural work processes undertaken by Sinan, the strong and deep knowledge of engineering science particularly in the field of civil engineering have enabled he produced a water supply system, bridge construction and building a strong and structured building structure that still stands today.

Generally, Sinan has made a lot of contributions to development in Turkey. Among his biggest contributions are the construction of water aqueducts, bridges and material and structure engineering.

\section{a. Water Aquedacts}

Water is a basic necessity to humans and all other lives. The construction of a good water aqueducts is indispensable to meet these basic needs. In this context Sinan's involvement has proven his knowledge and abilities in environmental engineering related to watter supply. According to Arioğlu and Arioğlu (17) besides Sinan occupational skill in dome solution, he was a talented water engineer. Furthermore, Kuran (18) mentioned from the 477 structures and structures produced by Sinan has succeeded in building 7 waterways to overcome the problem of water supply arising from the increase in population in Istanbul. Among the few channels that he built, the water system system known as the Kirkcesme System was the most powerful and admirable work of Sinan.

\section{b. Bridge Construction}

As a man who served as a military engineer, the task of constructing a bridge for the purpose of communication and warfare is between the duties of Sinan. According to Çeçen (19)Sinan built bridges and other similar engineering works before building mosque and madrasah.

As a result of Aptullah Kuran's research on the records contained in Tezkiretu'l Bunyan, Tezkiretu'l Ebniye and Tezkiretu'l Micmarin, he concluded that Sinan had succeeded in building nine bridges during his lifetime. According to historical records, between the bridge that Successfully built it is the Buyukcekceme Bridge, the Silivari Bridge, the Luleburga Bridge, the Sinan Bridge and the Mehmed Bridge which extends over the Drina River.

Sinan's success in building the Buyukcekceme Bridge is the best result of Sinan's work on the list of bridges construction work. According to Erzan (20) a bridge over the Buyukcekceme Lake is an impressive building where structural and aesthetic purposes integrate to create both rhythm and solidity.

\subsection{Sufism Elements in Sinan's Work and Contribution}

The uniqueness that should be addressed in discussing the success and excellence of Sinan's work in developing the territories of Tuki is the existence of the tasawuf or spiritual elements embodied in carrying out his work.

Although he started his life as a Christian and only gained exposure about Islam during his early twenties, Sinan was seen to have succeeded in making the policies revealed by Allah SWT through His Shari'ah as the fundamental principle that shaped his life. Not only in the context of performing special worship but Sinan has also exhibited a sense of appreciation of religious principles when fulfilling its obligations entrusted to him. This sense of appreciation has enabled him to form a balanced and balanced life perspective between his work process and his daily life in the teachings of Islam, namely faith, sharia and morals. 


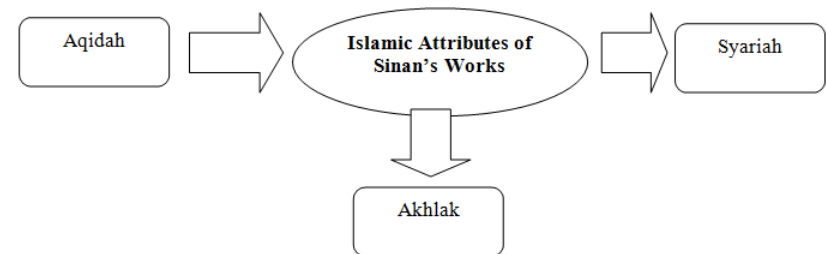

Fig.1: Model of Islamic Attributes of Sinan's Works

According to Ibn Kathir's interpretation, through this verse Allah SW has made a comparison between truth and falsehoods. Allah SWT likens the dirty bubbles that cover the surface of the water and the metal being melted as a fasting element which will eventually disappear and destroy. On the contrary, calm water that brings blessings to humans and metals such as gold, silver, iron and tinned ore to make equipment that benefits human beings will remain.

Sinan also embraces the concept of caliph that is from the point of view of providing stability and prosperity of life to mansion. This appreciation has made Sinan so careful, cautious and earnest in doing his job. Each of the projects to be undertaken and each building to be constructed sets the main features taken from the four caliphs named by Sinan as "The Four Chosen Friend".

Thus, Sinan has incorporated the elements of as-siddiq which are the truth and purity that represent the main attributes of Saidina Abu Bakar as Siddiq, justice, equality and sincerity that represent the main character of Saidina Umar al-Khattab, the kindness and sincerity that represents the main character of Saidina Uthman and the knowledge and knowledge that represented the main character of Saidina Ali bin Abi Talib. The combination of these elements has made Sinan produce designs either in the form of systems or architecture that bring prosperity to the inhabitants of the earth. This philosophy has also helped make Sinan's design a beneficial feature capable of preserving the universal human life.

\section{Conclusion}

Based on the analysis performed, Sinan had done a big contributions in field of civil engineering by focusing the construction of water aqueducts and bridges engineering. He also embedded the Islamic attributes in his works which were made it significant until today. Sinan not only succeeded in proving his greatness in engineering but he integrated it with daily life which was in scope of Islamic perspective.

\section{Acknowledgement}

This work was supported in part by Office For Research, Innovation, Commercialization and Consultancy Management (ORICC) University of Tun Hussein Onn Malaysia.

\section{References}

[1] Manzur I. Lisan al-'arab, 20 vols. Edited by Muhammad 'Abd alWahhab Beirut: Dar al-Ihya 'al-Turath al-'Arabi. 1997.

[2] Khaldūn I. al-Muqaddimah1980.

[3] Al-Attas MN. Islām and secularism: Muslim Youth Movement of Malaysia; 1978.

[4] Toynbee A. A Study of History, rev. and abridged by the author and Jane Caplan. New York: Oxford University Press; 1972.

[5] Hornby AS. Kamus Pembaca: Inggeris-Melayu: Fajar Bakti; 1972.

[6] Halim AA, Nor MRM, Ibrahim AZB, Hamid F. Ibn Khaldun's Theory of 'Asabiyyah and its application in modern Muslim society. Middle-East J Sci Res. 2012;11(9):1232-7.

[7] Nor MRM. Religious tolerance in Malaysia: An overview. MiddleEast Journal of Scientific Research. 2011;9(1):23-7.

[8] Abu-Munshar M. Islamic Jerusalem and its Christians: a history of tolerance and tensions: IB Tauris; 2007.
[9] Günüç F. The Fātih Complex I in the history of Turkish Culture and Civilization: Mosque, Madrasahs, Tombs, Library,. Darul Kurra, Guesthouse. 2007.

[10] İhsanoğlu E. Scholars of Andalusian Origin and their Contribution to Ottoman Science. Suhayl International Journal for the History of the Exact and Natural Sciences in Islamic Civilisation. 2015;14:948.

[11] İpşirli M. Ahizade Hüseyin Efendi. DİA, Türkiye Diyanet Vakfi yay, C I, İstanbul. 1988:548-9.

[12] Emiralioglu APP. Geographical Knowledge and Imperial Culture in the Early Modern Ottoman Empire: Ashgate Publishing, Ltd.; 2014.

[13] Kinross PBB. The Rise and Fall of the Turkish Empire: Cape; 1977.

[14] Lewis B. The Pro-Islamic Jews. Judaism. 1968;17(4):391.

[15] Shaw SJ, Shaw EK. History of the Ottoman Empire and Modern Turkey: Volume 2, Reform, Revolution, and Republic: The Rise of Modern Turkey 1808-1975: Cambridge University Press; 1976.

[16] Ihsanoglu E, Al-Hassani S. The Madrasas of the Ottoman Empire. Foundation for Science, Technology and Civilisation, Manchester Mathematics Education in the Balkan Societies Up To the WWI. 2004.

[17] Arioğlu N, Arioğlu E. Engineering Mystery of Master Architect Sinan's "Küfeki” Shell Limestone. Architectural Science Review. 2005;48(2):163-71.

[18] Kuran A. Sinan: the grand old master of Ottoman architecture: Institute of Turkish Studies; 1987.

[19] Çeçen K. Sinan's water supply system in Istanbul: Istanbul Technical University; 1992.

[20] Erzen JN. Video Art in Turkey. The Journal of Asian Arts \& Aesthetics. 2014(5):37-42. 